\title{
Modified Functional Impression Technique for Complete Dentures
}

\author{
Alexandre MALACHIAS \\ Helena de Freitas Oliveira PARANHOS \\ Cláudia Helena Lovato da SILVA \\ Valdir Antônio MUGLIA \\ Carla MORETO

\begin{abstract}
Department of Dental Materials and Prosthodontics, Faculty of Dentistry of Ribeirão Preto, University of São Paulo, Ribeirão Preto, SP, Brazil
\end{abstract}

\begin{abstract}
This report describes the use of a removable acrylic resin tray handle that can be easily attached to custom impression trays to produce an improved peripheral sealing zone. This device can be indicated to develop functional impressions for complete dentures using the patient-conducted muscular motion technique. In upper trays, the handle is fixed in the midline with acrylic resin, while in lower trays the centrally positioned handle is removed before border molding. This removable handle allows patient's suction and free tongue movements. Final impression is carried out in two stages: peripheral sealing (low fusion compound) and recording of the main supporting region of the denture (zinc oxide and eugenol paste). All border records are obtained from the patient's own movements (handle suction and tongue motion). The removable handle is simple to use, is reusable, can be adapted to any individual acrylic resin trays and allows accurate registration of the peripheral sealing zone (border tissues).
\end{abstract}

Key Words: complete dentures, functional final impressions, removable anterior tray handle.

\section{INTRODUCTION}

Stability of complete lower dentures has challenged dentists and patients alike. In particular, “flat lower ridge" is associated with difficulties in providing successful dentures $(1,2)$. Resorption rates vary from patient to patient and some authors have postulated several etiological factors related to residual (alveolar) ridge resorption, ranging from localized pressure to systemic factors (3).

Making accurate final impression for complete dentures is a multistage process that involves a preliminary impression, a customized final impression tray and a final border impression $(4,5)$. It is important to thoroughly examine the patient's mouth and select the most appropriate impression technique $(1,6)$. A major requirement for final impression of complete dentures is to develop the peripheral contours to accommodate normal muscular function and to ensure peripheral adaptation without allowing air penetration between the future denture base and the mucous membrane (7).

During the impression procedure, muscular zone record can be achieved by either the dentist or the patient or both. Many dentists pull on the patient's lips and cheeks to register the border areas (tissues surrounding the dentures) (8), which usually provides satisfactory border sealing zone (labial and buccal flanges). In the technique where muscular zone record is obtained with the patient's help, the patient is asked to make specific muscular movements of the lips, cheeks, tongue and jaws (open/closure and lateral). The use of an individual tray is necessary for this technique. The borders of this tray should be established in such a way that the patient's muscular movements are free from them during the impression procedure $(9,10)$.

This article describes the construction and use of a removable functional acrylic resin handle that can be attached to custom impression trays, allowing an excellent peripheral sealing zone impression using a patientconducted muscular and jaw motion technique. 


\section{MATERIAL AND METHODS}

Functional tray handles can be used with any individual acrylic resin trays.

These handles are made in a L-shaped metal master die (70 $\mathrm{mm}$ length and $7 \mathrm{~mm}$ in diameter), which is flasked in brass flasks (Safrany; J Safrany Dental metallurgy, São Paulo, SP, Brazil). After deflasking, the heat-polymerized acrylic resin (Clássico Dental Products, São Paulo, SP, Brazil) is pressed and molded according to the manufacturer's instructions to obtain the tray handle. Thereafter, the handle is finished and polished. Once the individual tray is prepared, the handle can be attached to its midline, positioned on the area corresponding to the crest of the ridge.

For the maxillary arch, the handle can be fixed to the tray using acrylic resin. For the mandible, an acrylic

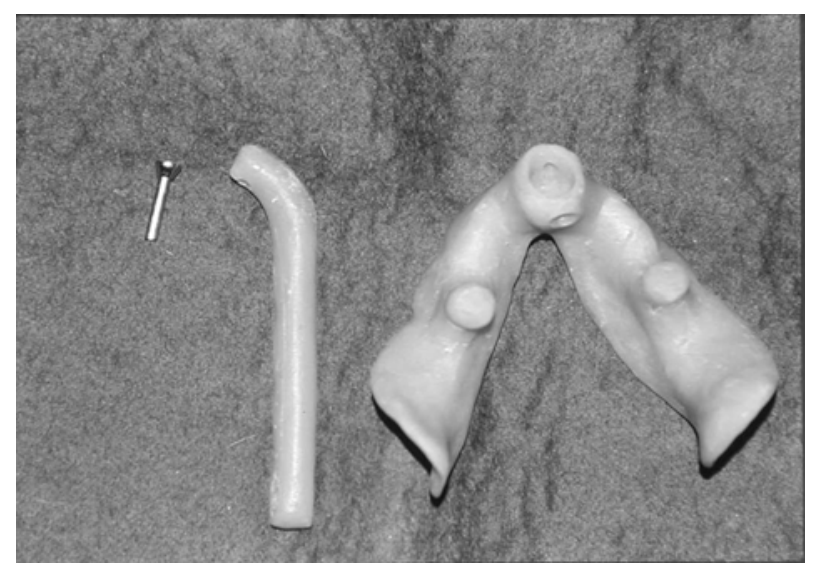

Figure 1. Functional removable acrylic resin handle, bolt, individual impression tray with the lateral supports in the area corresponding to the premolars/molars (upper view).

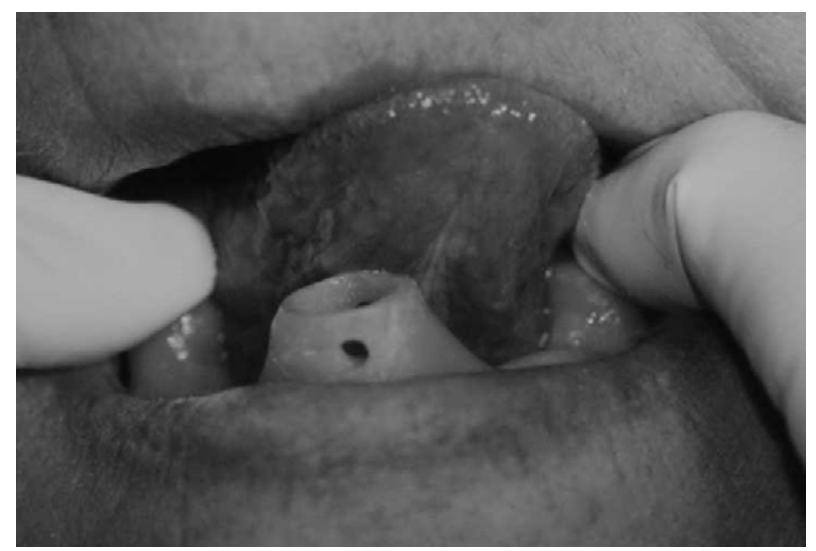

Figure 3. Mandibular individual impression tray held in position during patient's tongue movements to form the sublingual flange. resin base (15 $\mathrm{mm}$ high with a 10 -mm-diameter upper central hole) should be prepared and fixed to the individual tray on the residual ridge at its midline. The functional handle is further attached to the upper central hole with a bolt that is $11 \mathrm{~mm}$ long and has a diameter of $2 \mathrm{~mm}$ (Figs. 1 and 2).

This functional handle can be readily removed from the tray to facilitate molding of lingual and sublingual flanges borders with low fusion impression compound. The patient can freely move the tongue without interference from the tray handle. During this procedure, the tray is held in place by digital pressure of the dentist's right and left index fingers on the acrylic resin supports existing in the region of the tray corresponding to the first and second mandibular premolar (Figs. 3 and 4). During impression of buccal and labial flange borders, the functional handle is

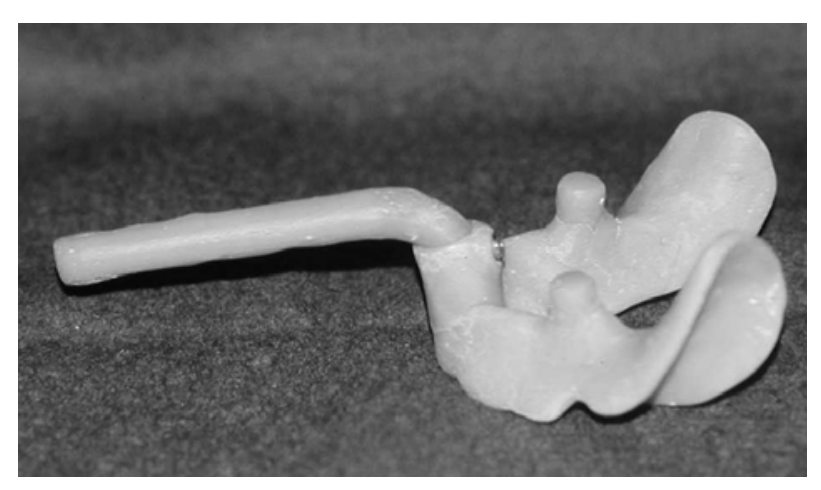

Figure 2. Functional removable acrylic handle fixed with the bolt to the central hole at the midline of the mandibular impression tray (lateral view).

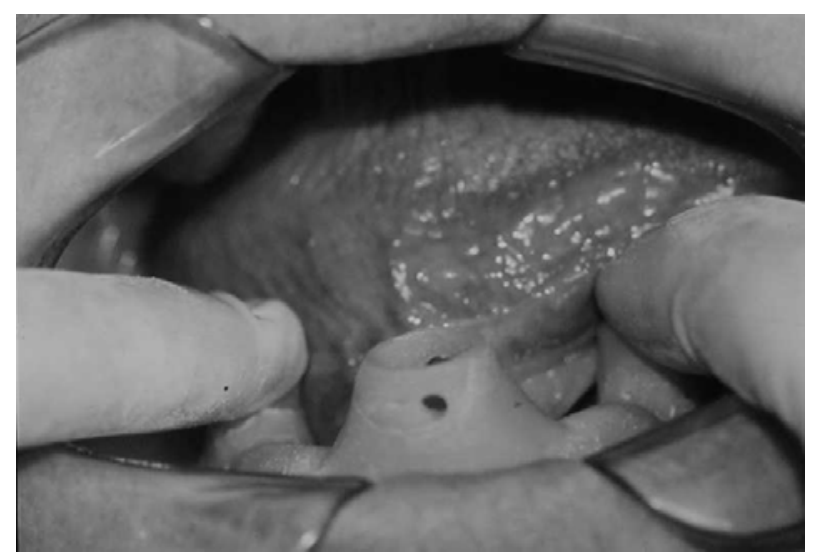

Figure 4. Patient's tongue movement to provide impression of the right lingual flange. 


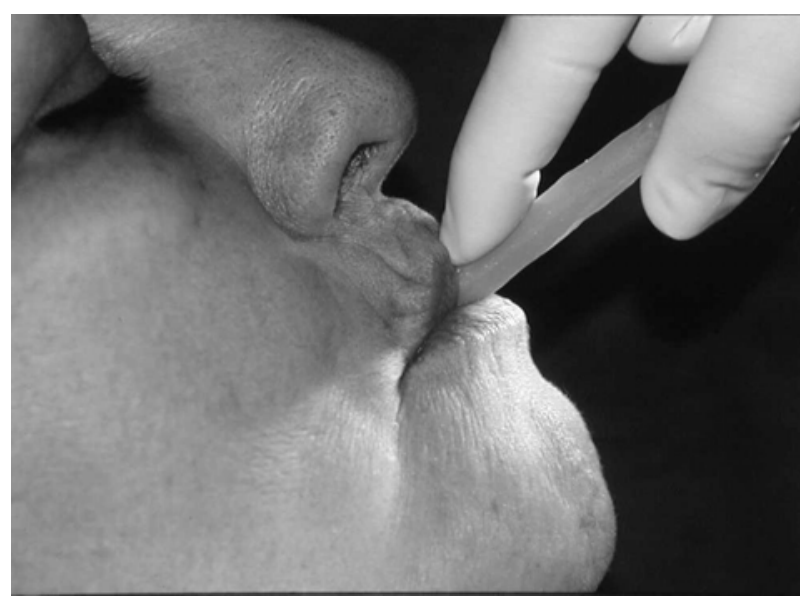

Figure 5. Vestibular peripheral sealing zone record (labial and buccal flanges), with the mandibular individual impression tray in position. Note the patient sucking on the functional handle during the impression procedure.

reattached to the tray and the patient is asked to perform a suction movement (Fig. 5).

The adjustments on the custom impression tray are done based on its stability while seated in the patient's mouth. The final impression is carried out in two stages using two types of materials. The first stage consists of border molding with low fusing impression compound. In the second stage, a zinc oxide-eugenol paste is applied to the main supporting surface of the impression. Using this final impression technique, border molding is obtained by the patient's own movements: suction in the maxillary arch and tongue movements and suction in the mandibular arch.

The upper tray is kept properly seated in position by the operator's thumb and index fingers. The handle is rotated (down and up, respectively) during suction on the handle to balance the tray loaded with impression material, to effectively force all of the peripheral muscles into maximum dynamic activity. The procedure does not cause any discomfort to the patient. Posterior border impression is enhanced using low fusion impression compound, with the dentist firmly seating the impression tray and pressing it against the central area of the palate. The impression is then completed with zinc oxide-eugenol paste and the loaded tray is gently seated in the patient's mouth. The patient is asked to suck on the functional handle again, while the dentist holds the tray in position.

For lower border molding, the functional handle is removed from the base by disconnecting the bolt, in such a way that the patient can move his/her tongue freely during the impression of the sublingual and lingual flanges. The dentist uses the acrylic resin molar supports at both sides of the tray, to keep it in position during this phase of the impression procedure.

For vestibular border impression, the handle is reattached to help introduce and hold the tray in place into the mouth and to facilitate suction by the patient. For lower impressions, during suction, the tray is balanced by the dentist's thumb pulling up and the index finger pressing down, a procedure opposite to that used for upper impressions.

As the border of the impression has been completed (Fig. 6), the next step is to record the main supporting surface of the final impression. The tray is loaded with zinc oxide-eugenol paste and gently seated into the patient's mouth. Once the tray is properly positioned with the material overflowing, the handle is removed again for recording the lingual and sublingual flanges. At this time, the dentist keeps the tray in position by pressing the resin molar supports while the patient performs tongue movements, as previously described, for approximately $20 \mathrm{~s}$. Finally, the handle is quickly reattached to the tray without removing the tray from the patient's mouth and the patient is asked to repeat the suction movements with the operator firmly holding onto the tray handle.

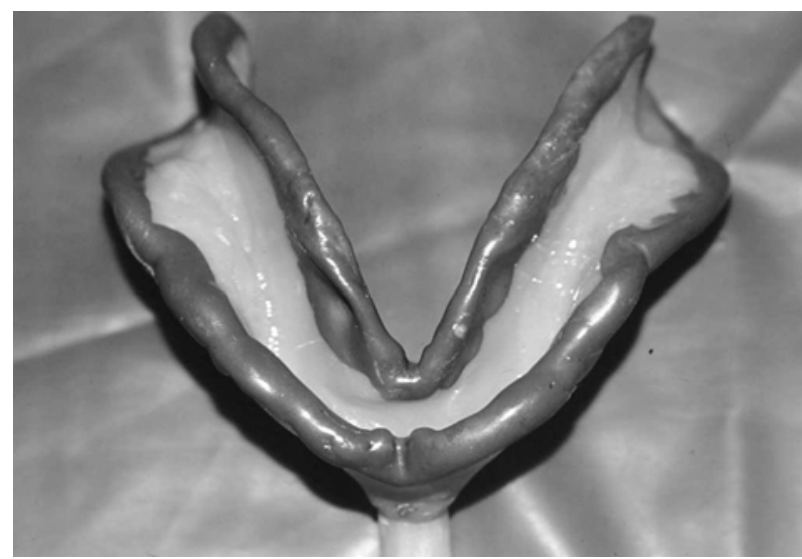

Figure 6. Peripheral impression completed.

\section{DISCUSSION}

Complete denture impression can be defined as a dynamic process that can be divided into two stages: preliminary impression and final impression. The aim on 
each patient is to fashion the impression surface and the peripheral rolls of the complete dentures in such a way that support, retention and stability of the denture are maximized (11). These two stages compliment each other. The initial impression should resemble the basic overall design for the complete denture. It also serves as the template for the final impression, helping to record the borders (edges) and the base area of the complete denture impression without distortion. During final impression using this technique, the muscular tissues, which may interfere with denture stability, can be identified and allowed for their functional movements. This warrants better border seal and improves retention and stability.

The peripheral sealing zone (border tissues) is an important region for denture retention and stability and should be precisely contoured during the final impression procedure. The dentist should develop an accurate custom tray and use an effective material and border molding technique. Several dynamic or functional impression methods, which we believe are particularly useful for patients with intense alveolar resorption, have been reported $(5,12,13)$.

The characteristics of functional impression techniques have not been widely investigated (14-16). It is common knowledge that each patient has his/her own specific muscular activity. Sometimes the contraction of a muscle near its insertion can displace the denture, unless it has a groove to accommodate such contractions. Clinical evidence about the interfering muscle region that might affect denture stability is difficult to detect in some patients. Therefore, the dentist should attempt to record all these individual aspects of the patient's labial and buccal anatomy in the final impression in order to permit normal muscle activity without loosing the denture during function.

The accuracy of complete denture impression techniques has been debated for many years. A wide diversity of denture border outlines, resulting from the use of the same impression procedure for all patients, has been shown and documented (17). Because each patient has his/her own distinct muscular strength and anatomy, it is important to individualize peripheral sealing zone impression. The functional handle was designed to effectively deal with this problem. Unlike other border molding techniques, which use manual traction of soft tissues, the functional handle permits muscular movements during the final impression, i.e., the patient can freely move the muscles, cheeks, lips and tongue without interference of the tray handle or the dentist's fingers. For individuals with an accentuated bone resorption, for example, it is difficult to obtain good retention and stability of the complete denture due to the presence of muscular insertions near the ridge crest or border, which might cause muscular-induced displacement of the denture. In these cases, this functional technique is highly recommended. The degree of muscular activity and the region to which the denture can be extended without displacement are important aspects of any impression technique.

The ordinary short tray handle used to guide the tray into the mouth may present problems and make it difficult to keep the tray in position. Suction around this type of custom tray handle is not easy and the tray can easily be dislocated. A possible solution would be to have the patient to suck on his/her own finger, but even this procedure may unseat the tray. The problem could be solved by asking the patient to suck the dentist's finger, but this is embarrassing for both patient and dentist and may also cause tray displacement and undesirable tissue displacement. On upper trays, if the dentist pushes the handle up, the tray moves in a posterior direction; if the dentist pulls the handle backwards, tissue displacement in both the palate and the tuberosity regions can occur. With lower trays, the situation is aggravated because both the pushing down and pulling back movements may cause undesirable tissue displacement in the anterior region or the tray may move in a posterior direction.

The functional removable acrylic resin handle hereby described offers a good support for correct positioning of the custom tray in the patient's mouth causing neither displacement on any surface of interest for impression nor displacement of the tray.

The handle works as a suctioning device for the patient and has the advantage of being removable on lower trays, facilitating the full and accurate impression of the sub-lingual flange region. To obtain a proper impression of this area, it is important to pay close attention to the normal posture of the tongue $(2,10,18,19)$ and it is necessary to seat the tray correctly, avoiding any dislocation during tongue movements. This can be achieved by removing the handle and holding the tray in place by pressing both lateral acrylic supports. In addition, the lateral supports can provide an ideal pressure distribution during the impression procedure and an 
unrestricted tongue access to most areas of interest. This is difficult to accomplish with ordinary anterior handles.

By sucking on the handle, the patient contributes to settle the final border design, delineating the location of individual muscle insertions. An upper denture may have some degree of movement during function even if it does not exhibit any movement during clinical examination. In fact, the characteristics of muscular insertion can easily be reproduced by using the suction technique because the muscular records are obtained from the patient's natural oral movements rather than by the dentist's handling. Manual border molding is guided by extrinsic forces that may hide traces or not reproduce some functional movements when excessive manual force is applied, which will over-shorten the flange height (20).

Malachias and Paranhos (10) described a similar functional handle made of metal. However, the acrylic resin removable functional handle, as described in this paper, is easy-handling, rapidly produced, readily attached to custom impression acrylic trays, less costly and available for all dentists in daily practice. Border tissues are recorded directly from the patient's functional movements (lips, tongue and cheeks), resulting in an accurate individualized impression process and producing excellent peripheral sealing. In our experience, it has worked well and yielded satisfactory results for patients being treated by dental students.

\section{RESUMO}

Este trabalho descreve o uso de um cabo funcional removível em resina acrílica que pode ser facilmente adaptado a moldeiras individuais para fornecer um bom registro da zona de selamento periférico. Este dispositivo pode ser indicado para moldagem final em prótese total utilizando a técnica de movimentação muscular realizada pelo paciente. Em moldeiras superiores, o cabo é fixado na linha mediana com resina acrílica, enquanto nas inferiores, a parte central do cabo é desmontável permitindo sua remoção antes da moldagem dos bordos laterais. O cabo removível é passível de sucção pelo paciente e permite que a língua seja movimentada livremente. A moldagem final é realizada em duas fases: moldagem da zona de selado periférico (godiva de baixa fusão) e da superfície de suporte (pasta de óxido de zinco e eugenol). Todos os registros musculares da zona de selado periférico são obtidos por meio de movimentação muscular realizada pelo paciente (sucção do cabo e movimentação lingual). O cabo funcional é reutilizável, permite um bom registro da zona de selado periférico (bordas teciduais) e pode ser adaptado a moldeiras individuais de resina acrílica devido à sua facilidade e simplicidade de uso.

\section{REFERENCES}

1. McCord JF, Grant AA, Quayle AA. Treatment options for the edentulous mandible. Eur J Prosthodont Restor Dent 1992;1:19-23.

2. Likeman PR. Tongue control of lower complete dentures: a clinical hint. Br Dent J 1997;182:229-230.

3. Atwood DA. The reduction or residual ridges: a major oral disease entity. J Prosthet Dent 1971;26:266-278.

4. Heartwell CM, Rahn AO. Syllabus of complete dentures. 4th ed. Philadelphia: Lea \& Febiger; 1986.

5. Zarb AZ, Bolender CL, Hickey JC, Carlsson GE. Boucher's prosthodontic treatment for edentulous patients. 10th ed. St Louis: C V Mosby; 1990.

6. Grant AA, Heath JR, McCord JF. Complete prosthodontics: problems, diagnosis and management. London: Wolfe; 1994

7. Suenaga K, Sato T, Nishigawa G, Minagi S. Relationship between size of complete foundation area and resorption of alveolar ridge in the edentulous mandible. J Oral Rehabil 1997;24:315-319.

8. Harvey WL, Brada BJ. An update of one-appointment master impression an jaw relation record technique. Quintessence Int 1992;32:547-550.

9. Klein IE, Broner AS. Complete denture secondary impression technique to minimize distortion of ridge and border tissues. J Prosthet Dent 1984;53:611-616.

10. Malachias A, Paranhos HFO. Functional metallic handles for final impressions of complete dentures. J Prosthet Dent 1998;79:607-608.

11. Jacobson TE, Krol AJ. A contemporary review of the factors involved in complete denture retention, stability and support. J Prosthet Dent 1983;49:5-15.

12. Basker RM, Davenport JC, Tomlin RH. Prosthetic treatment of the edentulous patient. 3rd ed. London: Macmillan; 1992.

13. McCord JF, Tyson KW. A conservative prosthodontic option of the treatment of edentulous patients with atrophic (flat) mandibular ridges. Br Dent J 1997;182:469-472.

14. Rapuano JÁ, Samanta A, Grieder A. Assuring successful impression making in complete dental construction. Clin Prev Dent 1987;9:23-26.

15. Gilbert Y, Blandin M. Technique originale de prise démpreinte secondaire en prothèse adjointe complète (PAC). Rev. D'odonto-Stomatol 1991;20:9-19.

16. Ivanhoe JR, Cibirka RM, Parr GR. Treating the modern complete denture patient: A review of the literature. J Prosthetic Dent 2002;88:631-635.

17. Woelfel JB, Hickey JC, Berg Tjr. Contour variations in one patient's impressions made by seven dentists. J Am Dent Assoc 1963;67:22-29.

18. Kotkin H, Slabebert JCG. Tongue position in relation to edentulous mandibular impressions. J Prosthet Dent 1987;57:458-466.

19. Basker RM, Watson CJ. Tongue control of upper complete dentures: a clinical hint. Br Dent J 1991;170:449-450.

20. McArthur DR. Management of the mucolabial fold when developing impressions for complete dentures. J Prosthet Dent 1985;53:62-67.

Accepted November 26, 2003 